\title{
Women's Rights Issues in EU-Serbia Relations
}

\author{
Galina A. Nelaeva and Nadezhda V. Dubiv* \\ Tyumen State University \\ 10 Semakova Str., Tyumen, 625003, Russia
}

Received 09.11.2016, received in revised form 22.07.2016, accepted 29.11.2016

\begin{abstract}
Starting from 1995, in the aftermath of the Beijing Conference, when the states discussed the question of the necessity of gender mainstreaming at all levels of policy-making, the European Union starts to promote the issue of gender equality not only at the EU level but also as a part of its foreign policy. Women's rights issues become an indispensable part of the accession process in its relations with candidate countries. The article considers the issue of incorporating gender aspects into the accession process in Serbia. Several problematic aspects are identified: protection of minority women (particularly, Roma), rights of most vulnerable women (single mothers, women with disabilities).
\end{abstract}

Keywords: European Union, women's rights, Serbia.

DOI: 10.17516/1997-1370-2016-9-12-2971-2977.

Research area: law, politology.

\section{Background:}

\section{EU enlargement in the Balkans}

European Union in its relations with candidate countries has continuously insisted upon the necessity to protect human rights. In the 1993 Copenhagen Criteria it was stated that applicant states must have not only functioning democratic institutions and market economy, but they also must respect the rule of law, ensure human rights protection and minority rights protection. Women's rights form an indispensable part of the idea of human rights protection. The process of EU enlargement to the Balkans has been more complex and difficult than the previous enlargements due to various reasons: first of all, post-Yugoslav states faced numerous problems related to post-war reconstruction and reconciliation; secondly, other actors, such as the International Criminal Tribunal for the former Yugoslavia (ICTY) took a direct part in the accession process (even though it was not meant to play a role like this initially) by imposing a condition upon member states to arrest and extradite suspects to the Hague, and thirdly, these countries still strive to address numerous internal problems related to poverty, ineffective institutions, minority-majority relations, etc. So far in this quest for membership Croatia has been the most successful country having joined the EU in 2013, while other post-Yugoslav states face uncertain prospects as far as full membership is concerned. This article looks at the issue of gender equality and women's rights more generally in the context of Serbia's accession process.

(C) Siberian Federal University. All rights reserved

* Corresponding author E-mail address: galinanelayeva@yahoo.com,nadjamich@mail.ru 
Theoretical framework:

women's rights issues

in the accession process

When discussing the issues of EU enlargement and EU relations with applicant states, researchers often refer to the theoretical school that focused on Europeanization. (Cowles, Caporaso, Risse, 2001). Although Europeanizaton is hard to define, while analyzing transformation processes taking place in Central and Eastern Europe, scholars emphasize a whole range of issues that fall within this term, including, inter alia, setting up and managing democratic institutions, division of competences at the European and national level, projecting European model of governance to non-European venues (Olsen, 2002). As Othon Anastasakis puts it, "Political conditionality is a strategy with both a substantive and an operational dimension, referring, on the one hand, to the message and the designated political criteria and, on the other, to the way the instrument is operated through deadlines, thresholds, and the practice of pressure from abroad. Both dimensions are particularly important and can affect the outcome of political transformation in a given situation" (Anastasakis, 2008: 367).

Europeanization normally operates on several levels. Thus, Geoffrey Pridham points out four groups of factors which are necessary to examine EU impact on domestic policies within applicant states. Among these groups of factors are a) historical, motivational and cultural factors; b) the factor of governance that comprises policy-oriented and institutional dimensions (adoption of the acquis). On this level a number of problems might arise when applicant states consider particular policies too expensive (environmental policy, for example) or when applicant states demonstrate poor performance in general in some issue-areas (such as minority rights); c) the political arena (with the media playing an important role at this level), which presupposes examination of positions of political parties towards EU integration and the influence of policy-makers on public opinion; d) the socioeconomic level: the ability of the economy to adjust to the acquis (Pridham, 2001).

A question can be raised as to why women's rights issues and gender equality become an indispensable part of EU conditionality policy towards the applicant states. We believe this decision corresponds to the general self-image of the European Union as a promoter and defender of human rights and the rule of law. As E.Weiner emphasizes, out of more than eighty thousand pages that form the core of acquis communautaire and are necessary for adoption in the candidate states, provisions on women's rights issues are relatively short. However, in the whole package of legal provisions they form a central part since they are closely linked to fundamental values that the EU is built upon (Weiner, 2009: 212). Weiner quotes the European Commission, which declared in its 2000 report that "Democracy is a fundamental value of the European Union, Member States, EEA States, and applicant countries. . . . Its full realization requires the participation of all citizens women and men alike to participate and be represented equally in the economy, in decision-making, and in social, cultural and civil life" (Weiner, 2009: 213). ${ }^{1}$ The European Commission also believes that gender equality is closely connected to the EU's aspirations to achieve economic growth and competitiveness (Equality between Women and Men..., 2006). Thus, both political and economic reasons are given to justify the incorporation of gender issues into the accession process.

In the process of integrating Central and Eastern European states into the EU the questions of gender equality played a prominent role. If the situation of women in some states (Slovenia, Poland, Czech Republic) was 
assessed as satisfactory, some states (Lithuania, Latvia, Hungary) were criticized for gender discrimination, low levels of women's participation in politics, the so-called "glass ceiling", low involvement of women in economic processes, lack of necessary training programs for women (Silovic, 2000). Therefore, addressing the abovementioned problems becomes a very important part for the EU in its enlargement strategy. Western Balkan states faced similar problems as the CEE states. However, a significant hurdle for the region was political instability due to the complexities of the post-conflict reconstruction, the role of international actors and third states in the political and economic processes in the region and unresolved questions (such as Kosovo status and minority rights protection).

\section{Serbia's EU Accession: incorporating women's rights into the internal law and politics}

The Stabilization and Association Process (SAP) for Western Balkans (namely, Bosnia and Herzegovina, Croatia, the Former Yugoslav Republic of Macedonia, Albania and Montenegro and Serbia, including Kosovo) was launched by the EU in the end of 1999. This process offered the states of Western Balkans a framework of cooperation with the EU. Among the suggested fields of cooperation were: "the development of economic and trade relations with the region and within the region; the development of the existing economicandfinancialaid; aidfordemocratisation, civil society, education and the development of institutions; cooperation in the field of justice and home affairs; the development of political dialogue" (The Stabilization and Association Process). In 2000 a new aid plan was adopted for Western Balkans and in 2003 the EU member states approved "Thessaloniki Agenda for the Western Balkans", in which the EU reiterated "its unequivocal support to the European perspective of the Western Balkan countries" (EU-Western Balkans Summit). Starting from 2003 Serbia has been working on necessary reforms meant to harmonize its legislation with the acquis. The very process of accession has been uneven due to a number of internal and external factors, for example, "problems related to the rule of law and the potential social consequences of the economic crisis", as well as inability of the EU to speak with one voice (Huszka, 2010:7-8).

One of the core questions as far as Serbia's human rights performance is concerned, has been women's rights and gender equality. It is worth noting that Yugoslavia was among the first states that ratified the UN CEDAW Convention (signed in 1980, ratified in 1982). However, the situation of women significantly deteriorated in the post-communist period. For instance, according to M. Erny, the percentage of women on the labor market used to be on the level of 60$80 \%$, currently it is not more than $44 \%$ (63\% for men). Unemployment rates are also high: $24 \%$ for women (16\% for men) (Erny, 2014: 206). "The employment rate indicates women's status in the economy: $62.5 \%$ in the EU and $44 \%$ in Serbia. The percentage of women entrepreneurs in the $\mathrm{EU}$ is $33 \%$, and in Serbia it is $23.3 \%$, and gender pay gaps are $17.8 \%$ and $16 \%$, respectively" (Ignjatovic, Boscovic, 2013: 426). And even if enrolment of women in universities is high (girls comprise more than $50 \%$ of students), they rarely choose natural sciences, giving preference to humanities.

According to the assessment of the European Commission, the most problematic issues for Serbia are women's health issues, representation of women in the media, gender-based violence and rights of vulnerable groups (such as single mothers, old women, rural women). Additional measures are necessary to fight gender-based discrimination and domestic violence, and ensure gender equality (especially in employment). 
Complex measures are necessary to integrate women with disabilities (European Commission Progress Report, 2013).

\section{Legislative and institutional reforms}

Despite the fact that the socio-economic and political situation in Serbia was difficult in the early 1990s, and women's rights issues were often ignored by the government, non-governmental organizations sought to ensure that these issues were addressed (Ignjatovic, Boscovic, 2013: 428). Serbian NGOs addressed several important issues: for instance, trafficking (a widespread problem in the region). ${ }^{2}$ Visible and strong women's NGOs worked on the issue of violence against women: they provided counselling to victims, shelters, maintained a SOS hot line, crisis centers, participated in international summits and other events. ${ }^{3}$ Special attention was paid to the problem of wartime violence against women, an important topic in the post-war Yugoslav states. ${ }^{4}$

Institutional reforms began in Serbia in the early 2000s onwards. In 2004 Serbia set up the Government of Serbia's Council for the Equality of Genders (which was later renamed the Council for Gender Equality). Gender equality issues were included in the political parties' programs, and in 2007 within the Ministry of Social Affairs it was decided to set up Directorate for Gender Equality (2007). This Directorate had a task to draft legislative improvements, monitor the situation and establish links with the UN CEDAW Committee. The Act on Gender Equality (Zakon o ravnopravnosti polova) was adopted in 2009. Necessary equality criteria were introduced, such as "quota of $30 \%$ for representation of women in political bodies". "Affirmative action is invoked in cases of unequal status of certain social groups. Article 14 of the GEA stipulates that a gender represented at a level of less than $30 \%$ in decision-making positions in public administration can be supported by affirmative measures"(Ignjatovic, Boscovic, 2013: 428).

Additionally, in 2009 Serbia adopted "The Strategy for the Advancement of Women and Gender Equality" for the period 2010-2015 and the Action Plan in 2010. Additionally, work started on drafting the National Anti-Discrimination Strategy (Petričević, 2012: 43).

There is also a Commissioner for the Protection of Equality, an autonomous specialized body, created in 2010 to combat gender-based discrimination. Additionally, there is a Deputy Ombudsperson who deals with gender equality, children's rights and persons with disabilities (elected in 2008). "In addition, the Office of the Ombudsperson has recently, in 2012, established a special expert advisory body or the Council for Gender Equality in order to tackle domestic violence and other gender related issues" (Petričević, 2012: 47).

Thus, in the decade of 2000s, necessary laws were adopted and new institutions were set up in order to harmonize Serbia's legislation and policies with the EU. Despite this, a number of problems remains: first of all, the problem of discrimination of women in employment. Women are not only more likely than men to lose their job, they are generally underpaid. According to the data of the organization Viktimološko društvo for the year 2012 год, $61 \%$ of women suffered from discrimination in employment, but only one out of ten asks for help. The most common forms of discrimination are interview questions in the recruiting process relating to marriage and children, as well as additional tasks at the workplace (such as making coffee) and comments concerning women's appearance (Petričević, 2012: 65).

An important issue as well is minority women's rights. As the European Commission points out, even if there are necessary laws for minority protection, implementation of these laws 
is uneven (especially in the field of education, use of minority languages, media participation, the right to religious rituals in a native language). This is especially true for the Roma minority, whose situation remains difficult. The same applies to refugees and internally displaced persons (European Commission Progress Report, 2013: 36).

Serbia's performance in the field of combatting domestic violence is also criticized. Instances of domestic violence are not only badly documented but also efforts to combat it are poorly coordinated. Projects do not get necessary funding, there are not enough shelters for women-victims of domestic violence. Insufficient training of professionals who work with victims is also mentioned as a serious problem (European Commission Progress Report, 2012: 15).

\section{Conclusion}

On the first and second levels, identified by Pridham (historical, motivational and cultural factors and governance) there were no major disagreements within the elites and the society at large. Even if the question of EU accession remains a highly contested issue, the country received its candidate status and its choice seems irreversible. Necessary institutional reforms in the field of gender equality are introduced and there is widespread consensus that progress in this field is necessary to achieve full membership. On the level of implementation, however, a number of problems remain. Despite legislative and institutional reforms, some questions remain problematic. The European Commission noted the progress of Serbia in the field of gender equality, however, additional efforts are necessary to combat gender-based discrimination and to fully integrate vulnerable women into the society (women with disabilities, single mothers, women from minorities). Special attention should be paid to Roma women and gender-based violence. In general, as researchers note, Serbia already meets some EU criteria (for instance, in the field of women in education), thus, we can expect progress on other questions as well, and positive assessment of Serbia's performance on the part of the EU.

\footnotetext{
See also: European Commission Communication from the Commission to the Council, the European Parliament, Economic and Social Committee and the Committee of the Regions: Towards a Community Framework Strategy on Gender Equality (2001-2005). URL: http://europa.eu/legislation_summaries/other/c10932_en.htm, last accessed 02.10.2014.

2 Astra Anti-Trafficking Action. URL: http://www.astra.rs, last accessed 09 October 2014.

3 Women Against Violence Network. URL: http://www.zeneprotivnasilja.net/en/about-us/wav-network, last accessed 09 October 2014

4 Women in Black. URL: http://zeneucrnom.org, last accessed 09 October 2014.
}

\section{References}

Anastasakis, O. (2008). The EU's Political Conditionality in the Western Balkans: Towards a More Pragmatic Approach, In Southeast European and Black Sea Studies, 8 (4), 365-377. DOI: 10.1080/14683850802556384

Astra Anti-Trafficking Action. Available at: http://www.astra.rs (accessed 19 October 2016).

Cowles, M. G., Caporaso, J., \& Risse, T. (2001). Transforming Europe: Europeanization and Domestic Change. Ithaca, Cornell University Press, 282 p.

Equality between Women and Men in the European Union. Brussels: Directorate-General for Employment, Social Affairs and Equal Opportunities. European Commission. 2006. Available at: http://ec.europa.eu/justice/gender-equality/document/index_en.htm\#h2-1, (accessed 14 October 2016). 
Erny, M. (2014). Gender and Democratization, In European Scientific Journal, 2, 198-213. Available: http://eujournal.org/index.php/esj/article/view/2891/2719 (accessed 20 October 2016).

European Commission Communication from the Commission to the Council, the European Parliament, Economic and Social Committee and the Committee of the Regions: Towards a Community Framework Strategy on Gender Equality (2001-2005). Available: http://europa.eu/ legislation_summaries/other/c10932_en.htm (accessed 12 October 2016).

European Commission Progress Report Serbia (2012), p. 15. Available at: http://ec.europa. eu/enlargement/pdf/key_documents/2012/package/sr_rapport_2012_en.pdf (accessed 12 October 2016).

European Commission Progress Report. Serbia (2013), p. 36. Available at: http://ec.europa.eu/ enlargement/pdf/key_documents/2013/package/sr_rapport_2013.pdf (accessed 12 October 2016).

EU-Western Balkans Summit. Thessaloniki (21 June 2003), Press Release. Available: http:// europa.eu/rapid/press-release_PRES-03-163_en.htm (accessed 15 October 2016).

Huszka, B. (February 2010). The Next Enlargement Round- the Balkan Challenge. In EU Frontiers Policy Paper, 1. Available: https://publications.ceu.edu/node/44741 (accessed 18 October 2016).

Ignjatovic, S., \& Boskovic A. (2013). 'Are we there yet?' Citizens of Serbia and public policy on gender equality within the EU accession context, In European Journal of Women's Studies, 20 (4), 425-440. DOI: 10.1177/1350506813478409

Olsen, J. (2002). The Many Faces of Europeanization, In Journal of Common Market Studies, 40, 921- 952. DOI: 10.1111/1468-5965.00403

Petričević, I. (2012). Women's rights in the Western Balkans in the Context of EU Integration: Institutional Mechanisms for Gender Equality, European Parliament: The Greens/European Free Alliance. Available: https://ravnopravnost.gov.hr/UserDocsImages/arhiva/images/pdf/ Izvje $\%$ C5\%A1\%C4\%87e_Womens\%20Rights $\% 20$ in $\% 20$ the $\% 20$ Western $\% 20$ Balkans $\% 20$ in $\% 20$ the \%20Context\%20of\%20EU\%20Integration.pdf (accessed 20 October 2016).

Pridham, G. (2001). EU Accession and Domestic Politics: Policy Consensus and Interactive Dynamics in Central and Eastern Europe, In Perspectives on European Politics and Society, 1 (1), 49-74. DOI: dx.doi.org/10.1080/1570585008458743

Silovic, D. (2000). EU accession - chance for gender equality in CEE countries, In European Review of Labour and Research, 6, 468-485. DOI: 10.1177/102425890000600310

The stabilisation and association process. Available: http://europa.eu/legislation_summaries/ enlargement/western_balkans/r18003_en.htm (accessed 19 October 2016).

Weiner, E. (2009). Enlargement Dirigism and Déjà Vu Logic: The Gender Politics and Perils of EU, In European Journal of Women's Studies, 16 (3), 211-228. DOI: 10.1177/1350506809105306

Women Against Violence Network. Available: http://www.zeneprotivnasilja.net/en/about-us/ wav-network (accessed 19 October 2016).

Women in Black. Available: http://zeneucrnom.org (accessed 19 October 2016). 


\title{
Отношения Сербии и ЕC:
}

\section{вопросы защиты прав женщин}

Г.А. Нелаева, Н.В. Дубив

Тюменский государственный университет

Россия, 625003, Тюмень, ул. Семакова, 10

\begin{abstract}
Начиная с 1995 года, когда состоялась международная конференция по правам женщин в Пекине, в ходе которой страны обсудили необходимость включить вопросы гендерного равноправия на все уровни политики, Европейский союз начинает продвигать идею защиты прав женщин и обеспечения равноправия полов не только во внутренней, но и во внешней политике, в том числе в отномениях со странами-кандидатами. В данной статье ставится иель рассмотреть, каким образом гендерные вопросы интегрированы в процесс расширения ЕС в странах Западных Балкан, а именно в Сербии. Особое внимание уделяется таким проблемам, как защита женщин-представительниц меньшинств (в частности цуыганского меньшинства), уязвимых слоев населения (женщин-инвалидов, матерей-одиночек).
\end{abstract}

Ключевые слова: Европейский союз, права женщин, Сербия.

Научная специильность: 12.00.00 - юридические науки, 23.00.00 - политология. 